\title{
THE EFFECTS OF NUTRITION ON THE REPRODUCTIVE PERFORMANCE OF FINN $\times$ DORSET EWES
}

\section{PLASMA PROGESTERONE AND LH GONGENTRATIONS DURING LATE PREGNANCY}

\author{
Y. SHEVAH, W. J. M. BLACK, W. R. CARR* AND R. B. LAND* \\ School of Agriculture, University of Edinburgh, and \\ *A.R.C. Animal Breeding Research Organization, Edinburgh EH9 $37 Q$
}

(Received 7th Fanuary 1975)

\begin{abstract}
Summary. Progesterone and LH concentrations were measured in the plasma of blood samples taken from forty-eight pregnant ewes on Days 100,120 and 134 of gestation. The ewes, in two groups of twenty-four were maintained from Day 100 until parturition on two planes of nutrition which supplied daily energy and protein intakes of about $4 \cdot 1$ or 2.3 Mcal metabolizable energy and either 192 or $111 \mathrm{~g}$ digestible crude protein per ewe. Within the groups, the ewes carried one, two or three fetuses and the feed intake was adjusted according to litter size to produce a uniform nutritional state within the group.

On Day 100, litter size affected the concentration of plasma progesterone $(P<0.001)$, but had no effect on Days 120 or 134 when the ewes were fed according to litter size. The low feed intake however caused a significant increase in plasma progesterone concentrations. The LH concentrations showed no major changes during late pregnancy and no effect of nutrition or litter size on the plasma hormone concentration was observed.

It was concluded that the effect of litter size on plasma progesterone concentration recorded on Day 100 of gestation was partly mediated by level of nutrition.
\end{abstract}

\section{INTRODUCTION}

In the sheep, plasma progesterone levels were found to increase from 2 to 3 $\mathrm{ng} / \mathrm{ml}$ in early pregnancy to about 10 to $20 \mathrm{ng} / \mathrm{ml}$ on Days 130 to 140 of gestation and to decline to below $1 \mathrm{ng} / \mathrm{ml}$ at parturition (see Bassett, Oxborrow, Smith \& Thorburn, 1969; Fylling, 1970). The concentration of LH, however, was relatively constant around $1 \mathrm{ng} / \mathrm{ml}$ during pregnancy and parturition (Niswender, Roche, Foster \& Midgley, 1968). Although most workers agree on the general patterns, they all indicated a wide variation in the concentration of circulating hormones among individual ewes. The plasma progesterone concentration was found to be related to the number of fetuses carried by the ewe (Bassett et al., 1969; Fylling, 1970), and a low level of nutrition affected the maternal plasma progesterone concentration in early pregnancy in sheep 
(Cumming \& co-authors, 1971) and in mid- and late pregnancy in cows (Donaldson, Bassett \& Thorburn, 1970).

The present experiment was designed to study the combined effects of nutrition and litter size on the plasma levels of progesterone and LH.

\section{Animals and treatments}

\section{MATERIALS AND METHODS}

The experimental animals were taken from a flock of Finnish Landrace $x$ Dorset Horn (Finn $\times$ Dorset) ewes (average age 3 years, range 2 to 5 years), and were mated on the same day in late July 1972 following progestagen treatment to synchronize oestrus. After mating, the ewes grazed pasture until the end of October when forty-eight were selected and allocated to two groups balanced for age, live weight and number of fetuses (determined by X-ray examination). The ewes within each group were individually penned and fed a pelleted complete ruminant diet (Shevah, Black \& Land, 1975) at two constant levels throughout the experiment. The first of these (Group H), provided a daily maintenance energy level of $33 \mathrm{Kcal}$ metabolizable energy (ME)/kg live weight of the ewe at the start of treatment, plus a fetal allowance of $365 \mathrm{Kcal}$ $\mathrm{ME} / \mathrm{kg}$ for anticipated lamb birth weights of $3.5,6.5$ and $8.2 \mathrm{~kg}$ for singles, twins and triplets respectively (Land \& McClelland, 1971). The second (Group L) provided half the total energy allocated to ewes to Group H. In this way, it was intended that the nutritional state of the ewes within a treatment group would not be influenced by the number of fetuses carried.

Live weights were recorded once weekly before feeding, and blood samples were taken before feeding on the same day each week for analysis of blood metabolites, and on Days 100, 120, 134 and 141 for hormone assays. Blood samples were taken from the jugular vein into heparinized evacuated tubes. Soon after withdrawal, the samples were centrifuged, and the plasma was drawn off and stored at $-15^{\circ} \mathrm{C}$ pending analysis. On the 141 st day of gestation between 20.00 and 21.00 hours, the ewes were injected intramuscularly with $16 \mathrm{mg}$ dexamethasone (Berk Pharmaceutical Ltd, Surrey) to induce parturition (Shevah, 1974) and the lambing data were recorded.

\section{Plasma non-esterified fatty acids}

These (FFA) were determined by the method described by Patterson (1963), and were used as an indication of nutritional state (Patterson, 1963; Shevah et al., 1975).

\section{Hormone assays}

Progesterone. Plasma levels were determined by radioimmunoassay, based on the method of Hotchkiss, Atkinson \& Knobil (1971) and described by Furr (1973). The efficiency of extraction for thirty samples in the nine assays (mean \pm S.E.) was $76.3 \pm 1.4 \%$. The addition of $100 \mu \mathrm{l}$ of a 1:4000 dilution of caprine antiserum to each tube bound $50 \%$ of the $\left[{ }^{3} \mathrm{H}\right]$ progesterone, and a distilled water blank gave a concentration which never exceeded $5 \mathrm{pg} / \mathrm{ml}$. Samples from a pool of plasma obtained from ewes on the day of parturition were included in every assay and these gave a mean concentration of $0.38 \pm 0.03$ $\mathrm{ng} / \mathrm{ml}$ (nine assays) and an inter-assay coefficient of variation of $16.7 \%$. 
$L H$. Plasma levels were determined by a double-antibody radioimmunoassay described by Carr \& Land (1975), using a specific equine (antibovine LH) antiserum.

\section{Nutritional status}

\section{RESULTS}

The successful adjustment of the diet of the ewes to eliminate the effects of litter size within the high and low treatments was of critical importance, and the measurements of plasma FFA concentration and live body weight changes are given in Table 1. The mean plasma FFA concentration was similar for ewes carrying one, two or three fetuses within the high treatment, and, although litter size did have a small and significant effect $(P<0.05)$ when tested by analysis of variance within the low treatment, there was a much greater difference between treatments $(P<0 \cdot 001)$. Similarly, the ewes on the high energy diet gained an average of approximately $8 \mathrm{~kg}$ during the last 6 weeks of gestation, whereas those on the low diet only maintained their body weight.

Table 1. Mean feed intake and the performance of pregnant ewes on high $(\mathrm{H})$ and low (L) nutritional levels which were adjusted according to litter size during late pregnancy

\begin{tabular}{|c|c|c|c|c|c|c|c|c|c|}
\hline \multirow[b]{2}{*}{ Group } & \multirow{2}{*}{$\begin{array}{c}\text { No. of } \\
\text { fetuses/ } \\
\text { erve }\end{array}$} & \multirow{2}{*}{$\begin{array}{l}\text { No. of } \\
\text { ewes }\end{array}$} & \multirow{2}{*}{$\begin{array}{l}\text { Energy intake } \\
\left(M_{\text {cal }} M E /\right. \\
\quad \text { day })\end{array}$} & \multirow{2}{*}{$\underset{(\mathrm{kg})}{\text { Body gain } \dagger}$} & \multicolumn{3}{|c|}{ Plasma FFA $\ddagger$ ( $\mu$ equiv./litre) } & & \multirow{2}{*}{$\begin{array}{c}\text { Total lamb } \\
\text { weight }(\mathrm{kg})\end{array}$} \\
\hline & & & & & $\overline{\text { Day } 100}$ & & $\begin{array}{c}\text { Day } 100 \\
\text { to parturition }\end{array}$ & & \\
\hline \multirow[t]{2}{*}{$\overrightarrow{\mathrm{H}}$} & $\begin{array}{l}1 \\
2 \\
3\end{array}$ & $\begin{array}{r}7 \\
7 \\
10\end{array}$ & $\begin{array}{l}3 \cdot 8 \pm 0 \cdot 1 \\
4 \cdot 0 \pm 0 \cdot 1 \\
4 \cdot 4 \pm 0 \cdot 1\end{array}$ & $\begin{array}{l}7 \pm 0.9 \\
9 \pm 0.9 \\
9 \pm 0.8\end{array}$ & $\left.\begin{array}{l}766 \pm 14 \\
874 \pm 10 \\
872 \pm 10\end{array}\right\}$ & N.S. & $\left.\begin{array}{l}541 \pm 65 \\
631 \pm 65 \\
577 \pm 54\end{array}\right\}$ & N.S. & $\begin{array}{l}4.6 \pm 0.6 \\
7.6 \pm 0.6 \\
9.2 \pm 0.5\end{array}$ \\
\hline & Total & 24 & $4 \cdot 1 \pm 0.07$ & $8 \pm 0.5$ & $851 \pm 6$ & & $582 \pm 35$ & & $7 \cdot 4 \pm 0 \cdot 3$ \\
\hline \multirow[t]{2}{*}{$\mathrm{L}$} & $\begin{array}{l}1 \\
2 \\
3\end{array}$ & $\begin{array}{r}5 \\
10 \\
9\end{array}$ & $\begin{array}{l}1 \cdot 9 \pm 0 \cdot 2 \\
2 \cdot 1 \pm 0 \cdot 1 \\
2 \cdot 7 \pm 0 \cdot 1\end{array}$ & $\begin{array}{r}-3 \pm 1 \cdot 1 \\
0 \pm 0.8 \\
2 \pm 0.8\end{array}$ & $\left.\begin{array}{l}721 \pm 13 \\
913 \pm 12 \\
834 \pm 10\end{array}\right\}$ & N.S. & $\left.\begin{array}{r}794 \pm 76 \\
1054 \pm 54 \\
1042 \pm 57\end{array}\right\}$ & * & $\begin{array}{l}4.2 \pm 0.7 \\
6.8 \pm 0.5 \\
9.2 \pm 0.5\end{array}$ \\
\hline & Total & 24 & $2 \cdot 3 \pm 0.07$ & $0 \pm 0.5$ & $829 \pm 11$ & & $995 \pm 35$ & & $7 \cdot 1 \pm 0 \cdot 3$ \\
\hline
\end{tabular}

Values are means \pm S.E.M.

$* P<0.05$ (analysis of variance); N.S., not significant.

† Total gain during the last 6 weeks of gestation.

$\ddagger$ Galculated from the mean of six weekly means.

Plasma hormone levels

These are shown in Table 2.

Progesterone. The presence of twin and triplet lambs markedly influenced the progesterone concentrations on the 100th day of gestation. The mean plasma progesterone concentration of the thirty-six ewes carrying twins or triplets was significantly greater $(P<0.001)$ than that of the twelve ewes carrying a single fetus (Table 2).

The mean plasma progesterone concentrations of all animals in Group $\mathrm{H}$ was lower than that of those in Group L between Day 100 and parturition; on Day 120 of gestation, the concentration was $17 \cdot 8 \pm 0.95 \mathrm{ng} / \mathrm{ml}$ in the Group $\mathrm{L}$ ewes compared with $14.2 \pm 0.95 \mathrm{ng} / \mathrm{ml}$ in Group $\mathrm{H}$ ewes $(P<0.05)$. Within each treatment, however, the differences between ewes bearing one, two or three 


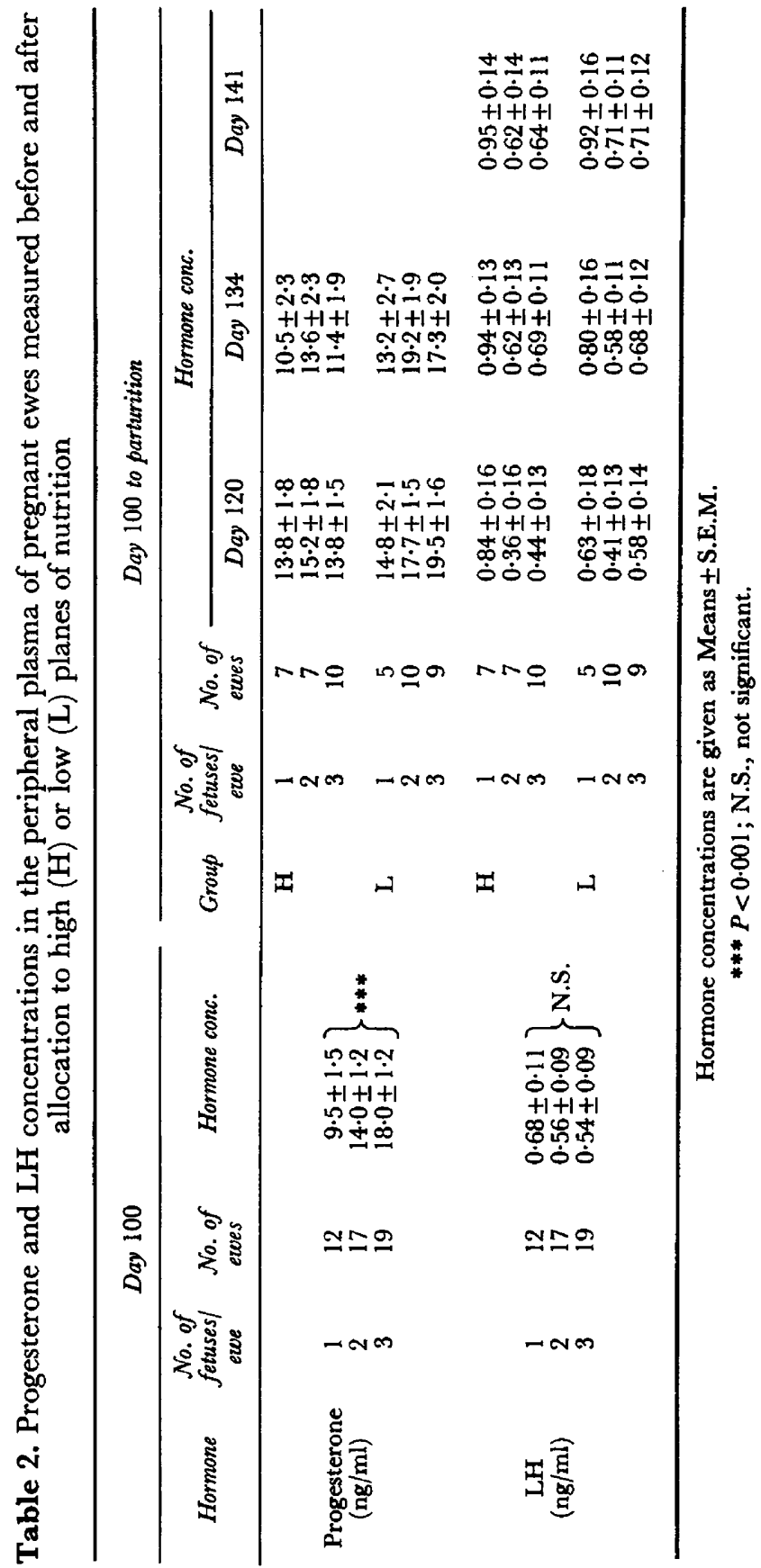


lambs were much less than on Day 100, especially in Group $\mathrm{H}$, and were not statistically significant in either group on Days 120 or 134 .

The relationships between litter size, plasma progesterone and plasma FFA concentrations were studied by least square analysis. At Day 100, litter size had a highly significant effect on progesterone concentration $(\mathrm{F}=7.9 ; 3$ and 43 d.f.; $P<0.001$ ) but had no significant effect on FFA levels. Conversely, the regression of litter size on progesterone level was also highly significant $(\mathrm{F}=$ $25.5 ; 1$ and 43 d.f.; $P<0.001$ ). The regression of litter size on FFA was not significant. On Days 120 and 134 of gestation, however, when an apparently uniform state of nutrition was achieved within treatments, there was no evidence that litter size affected either progesterone or FFA levels. Progesterone levels were no longer a good indication of litter size.

A highly significant correlation was found between progesterone and FFA concentrations before and after allocation to the nutritional treatments. The pooling of sums of squares and cross-products calculated within litter sizes gave correlations above 0.9 for Days 100, 120 and 134 in both treatment groups.

$L H$. The concentrations of $\mathrm{LH}$ in the maternal plasma did not differ significantly in ewes in Groups $\mathrm{H}$ and $\mathrm{L}$ and were not influenced by the number of fetuses carried by the ewe. The concentration remained in the range of 0.4 to 1.0 $\mathrm{ng} / \mathrm{ml}$ throughout the last third of gestation, with a slight but non-significant rise toward the end of gestation.

\section{DISGUSSION}

The plasma progesterone concentrations measured in the present study by a radioimmunoassay technique were similar to the values obtained by previous workers who used competitive protein-binding techniques (Bassett et al., 1969; Fylling, 1970; Obst, Seamark \& McGowan, 1971; Stabenfeldt, Drost \& Franti, 1972); a gradual increase occurred up to Days 130 to 140 of pregnancy and was followed by a decline before the end of gestation.

In the present study, the progesterone concentration measured on Day 100, before allocation to the nutritional treatments, was significantly affected by the number of lambs, as observed by Bassett et al. (1969) and Gadsby, Heap, Powell \& Walters (1972). In addition, the plasma progesterone concentrations were also significantly correlated with plasma FFA, indicating that the variation in progesterone levels did not arise from variation in litter size alone and other factors such as nutrition are likely to be involved. An increase in plasma progesterone levels during undernutrition of the ewe in early pregnancy was reported by Cumming et al. (1971).

When the effects of differences in nutrition were removed biologically by adjusting the diet to the demands of the fetuses, the effect of litter size on progesterone concentration disappeared, but a strong relationship between progesterone and FFA remained. It is possible, therefore, to conclude that the concentration of plasma progesterone is associated both with litter size and with FFA concentration, and that these associations may interact with the stage of gestation and the level of nutrition. Thus, the higher progesterone levels found in Group L ewes, combined with the absence of a relationship between progesterone and litter size when the ewes achieved a uniform nutritional state, 
stress the effect of nutrition on the maternal plasma progesterone and indicate the use of plasma progesterone as a possible criterion for the assessment of nutritional state in sheep. Cumming et al. (1971) suggested that the increase in plasma progesterone may be due to decreased metabolic rate, mobilization of stores of progesterone or increased rate of secretion. The change in plasma progesterone was not, however, accompanied by a change in LH or ACTH levels (Cumming et al., 1971) and, in the present study, the changes of LH concentrations were different from those of progesterone and no direct relationship could be seen. The rise in plasma progesterone during undernutrition in the ewe may have evolved to reduce pregnancy loss during periods of undernutrition, but the cause remains unclear.

\section{AGKNOWLEDGMENTS}

We wish to thank Dr Kathleen Birchall for help with the progesterone assay and Dr B. J. A. Furr and Dr R. B. Snook for the antisera against progesterone and $\mathrm{LH}$, respectively. We are also grateful to Mr D. I. Sales for the leastsquare analysis and Mr J. FitzSimons, Mr A. J. Cowe, Mr J. G. S. Duncan and Mr J. A. Ferguson of the Edinburgh School of Agriculture for the care of the animals. One of us (Y.S.) is grateful for the financial support of the Perry Foundation.

\section{REFERENGES}

Bassett, J. M., Oxborrow, T. J., Smith, I. D. \& Thorburn, G. D. (1969) The concentration of progesterone in the peripheral plasma of the pregnant ewe. 7. Endocr. 45, 449-457.

GARR, W. R. \& LAND, R. B. (1975) Plasma luteinizing hormone levels and testis diameters of ram lambs of different breeds. 7. Reprod. Fert. 42, 325-333.

Gumming, I. A., Mole, B. J., Obst, J., Blockey, M. A. de B., Winfield, G. G. \& Goding, J. R. (1971) Increase in plasma progesterone caused by undernutrition during early pregnancy in the ewe. 7. Reprod. Fert. 24, 146-147, Abstr.

Donaldson, L. E., Bassett, J. M. \& Thorburn, G. D. (1970) Peripheral plasma progesterone concentration of cows during puberty, oestrous cycle, pregnancy and lactation and the effects of undernutrition or exogenous oxytocin on progesterone concentration. F. Endocr. 48, 599-614.

FURR, B. J. A. (1973) Radioimmunoassay of progesterone in peripheral plasma of the domestic fowl in various physiological states and in follicular venous plasma. Acta endocr., Copenh. 72, 89-100.

Fylling, P. (1970) The effect of pregnancy, ovariectomy and parturition on plasma progesterone level in sheep. Acta endocr., Copenh. 65, 273-283.

Gadsby, J. E., Heap, R. B., Powell, D. G. \& Walters, D. E. (1972) Diagnosis of pregnancy and of the number of fetuses in sheep from plasma progesterone concentrations. Vet. Rec. 90, 339-342.

Hotchkiss, J. E., Atkinson, L. E. \& KNoBil, E. (1971) Time course of serum oestrogen and LH concentrations during the menstrual cycle of the Rhesus monkey. Endocrinology, 89, 177-183.

LAND, R. B. \& MCGLELLAND, T. H. (1971) The performance of Finn-Dorset sheep allowed to mate four times in two years. Anim. Prod. 13, 637-641.

Niswender, G. D., Roche, F. J., Foster, D. L. \& Midgley, A. R. (1968) Radio-immunoassay of serum levels of LH during the cycle and early pregnancy in ewes. Proc. Soc. exp. Biol. Med. 129, 901-904.

Obst, J. M., Seamark, R. F. \& McGowan, G. J. (1971) Plasma progesterone concentrations during pregnancy and parturition of ewes grazing Yarloop clover. F. Reprod. Fert. 26, 259-262.

Patterson, D.S.P. (1963) Some observations on the estimation of non-esterified fatty acids concentrations in cow and sheep plasma. Res. vet. Sci. 4, 230-237.

Shevah, Y. (1974) A note on the use of dexamethasone for induction of parturition of Finn $\times$ Dorset ewes. Anim. Prod. 18, 89-92.

Shevah, Y., BLAck, W. J. M. \& LAND, R. B. (1975) Variation of feed intake and the performance of Finn-Dorset ewes in late pregnancy. Anim. Prod. (in press).

Stabenfeldt, G. H., Drost, M. \& Franti, C. E. (1972) Peripheral plasma progesterone levels in the ewe during pregnancy and parturition. Endocrinology, 90, 144-150. 